\title{
Pelatihan Tentang Perawatan dan Upaya Pencegahan Tuberkulosis
}

\author{
Sri Darmawan ${ }^{1 *}$, Sriwahyuni $^{2}$
}

1*. STIKES Nani Hasanuddin Makassar, Jl. Perintis Kemerdekaan VIII, No. 24, Kota Makassar, Indonesia, 90245

2. STIKES Nani Hasanuddin Makassar, Jl. Perintis Kemerdekaan VIII, No. 24, Kota Makassar, Indonesia, 90245

*email : sridarmawan97@yahoo.com

\begin{abstract}
Abstrak
Pada kegiatan ini melibatkan lokasi kemitraan yaitu diwilayah kerja Puskesmas Tamalanrea, Kecamatan Tamalanrea Kota Makassar dengan tujuan memberikan pelatihan tentang cara perawatan dan upaya pencegahan Tuberkulosis (TB) sehingga dapat mengurangi terjadinya penyakit infeksi seperti Tuberculosis. Adapun metode yang digunakan adalah dengan cara memberikan penyuluhan yang disertai dengan pelatihan serta tanya jawab kepada sasaran atau peserta termasuk kader posyandu yang ada diwilayah kerja Puskesmas Tamalanrea, Kecamatan Tamalanrea Kota Makassar. Hasil dari kegiatan program kemitraan ini diharapkan sesuai tujuan yang target yang dapat dievaluasi melalui peran serta dan keaktifan para peserta selama kegiatan berlangsung.
\end{abstract}

Kata Kunci : Pelatihan, Perawatan, Pencegahan, Tuberkulosis

\section{Pendahuluan}

Tuberkulosis (TB) adalah penyakit menular langsung yang disebabkan oleh kuman Mycobacterium tuberculosis. Sebagian besar kuman Mycobacterium tuberculosis menyerang paru, tetapi dapat juga mengenai organ tubuh lainnya, World Health Organization (WHO) menyatakan bahwa sepertiga penduduk dunia telah terinfeksi kuman tuberkulosis. Setiap detik ada satu orang yang terinfeksi kuman tuberkulosis.(Rahmayuli et al., 2018).

Diagnosis TB ditegakkan berdasarkan gejala klinis, pemeriksaan fisik, pemeriksaan bakteriologi, radiologi dan pemeriksaan penunjang lainnya Metode baku emas (gold standard) dari pemeriksaan TB yaitu pemeriksaan kultur atau biakan dahak. Pemeriksaan 3 spesimen dahak Sewaktu-Pagi-Sewaktu (SPS) secara mikroskopis nilainya sama dengan pemeriksaan dahak secara kultur. Dan hasil pemeriksaan secara mikroskopis dinyatakan positif apabila sedikitnya dua dari 3 spesimen dahak (SPS) bakteri tahan asam (BTA) hasilnya positif. (Mulyadi, 2011)

Pada tahun 2016 ditemukan jumlah kasus tuberkulosis sebanyak 351.893 kasus, meningkat bila dibandingkan semua kasus tuberkulosis yang ditemukan pada tahun 2015 yang sebesar 330.729 kasus. Jumlah kasus tertinggi yang dilaporkan terdapat di provinsi dengan jumlah penduduk yang besar yaitu Jawa Barat, Jawa Timur dan Jawa Tengah. Kasus tuberkulosis di tiga provinsi tersebut sebesar $44 \%$ dari jumlah seluruh kasus baru di Indonesia. Menurut jenis kelamin, jumlah kasus pada laki-laki lebih tinggi daripada perempuan yaitu 1,4 kali dibandingkan pada perempuan. Pada masing-masing provinsi di seluruh Indonesia kasus lebih banyak terjadi pada laki-laki dibandingkan perempuan(Kementerian Kesehatan Republik Indonesia, 2017)

Dalam suatu unit pelayanan kesehatan seperti Puskesmas tidak mungkin dapat dipisahkan dengan tenaga-tenaga ahli yang berada di dalamnya satu diantaranya adalah perawat. Perawat adalah seseorang (seorang profesional) yang mempunyai kemampuan, tanggung jawab, dan kewenangan dalam melaksanakan pelayanan/asuhan keperawatan pada berbagai jenjang pelayanan perawatan, Peran perawat sangat penting, tidak hanya sebagai pemberi layanan namun juga sebagai edukator, mengingat banyaknya faktor penyebab terjadinya infeksi nosokomial karena perilaku masyarakat terhadap pencegahan penularan TB paru dan bagaimana seharusnya bersikap terhadap orang-orang yang terdiagnosis TB paru tersebut sehingga tidak terjadi penularan.(Studi et al., 2018) Amat terlebih dalam hal ini bagaimana seharusnya keluarga klien yang terdiagnosa TB paru mengetahui secara jelas dan seperti apa sebenarnya penyakit TB paru ini, dan bagaimana cara penularan dan pencegahannya. (Amalaguswan, Junaid and Fachlevy, 2017)

Faktor lain yang memiliki peranan dalam penularan penyakit tuberkulosis ini adalah lingkungan yang buruk sangat mendukung aktifnya dan berkembangnya bakteri Mycobacterium tuberculosis dengan baik. Kondisi rumah yang padat penghuninya juga dapat membantu penyebaran bakteri TB paru dan yang minim cahaya matahari atau cahaya lampu menyebabkan bakteri TB paru dapat bertahan sehingga mempunyai peluang besar untuk menimbulkan kasus TB selain itu lingkungan fisik rumah dan perilaku dengan kejadian tuberkulosis yang potensi penularannya ke anggota keluarga cukup besar jika tidak dikendalikan sejak dini.(Iwata and Uchida, 1991)

Sumber penularan TB adalah pasien TB BTA positif, Pada waktu batuk atau bersin, pasien menyebarkan kuman ke udara dalam bentuk percikan dahak (droplet nuclei). Sekali batuk dapat menghasilkan sekitar 3000 percikan dahak, 
Umumnya penularan terjadi dalam ruangan dimana percikan dahak berada dalam waktu yang lama, Ventilasi dapat mengurangi jumlah percikan, sementara sinar matahari langsung dapat membunuh kuman. Percikan dapat bertahan selama beberapa jam dalam keadaan yang gelap dan lembab, Daya penularan seorang pasien ditentukan oleh banyaknya kuman yang dikeluarkan dari parunya. Makin tinggi derajat kepositifan hasil pemeriksaan dahak, makin menular pasien tersebut, Faktor yang memungkinkan seseorang terpajan kuman TB ditentukan oleh konsentrasi percikan dalam udara dan lamanya menghirup udara tersebut, terjadinya kondisi yang seperti ini maka diperlukan adanya kemapuan atau skill anggota keluarga ataupun pendamping dari pasien seperti mengajarkan buang dahak pada wadah yang telah diberikan pasir atau cairan_antiseptik seperti sabun, mengajarkan tentang Personal Hygiene dll, hal ini merupakan salah satu cara yang dapat mencegah meningkatnya kejadian Penyakit Tuberkulosis (Mustikawati, 2011)

Berdasarkan realita tersebut maka kami ingin mengambil peran untuk membantu menurunkan prevalensi angka kejadian Penyakit Tuberkulosis sehingga diharapkan dapat meningkatkan derajat kesehatan masyarakat pada umunya dan masyarakat Tamalanrea Makassar pada khusunya

\section{Metode}

Metode pelaksanaan dari kegiatan ini adalah memberikan penyuluhan terlebih dahulu kepada masyarakat di wilayah kerja Puskesmas Tamalanrea Makassar yang selanjutnya diberikan pelatihan kepada peserta dengan tahapan sebagai berikut :

a. Pengenalan dan Persiapan

Sebelum melakukan penyuluhan dan pelatihan kepada masyarakat dan kader terlebih dahulu melakukan kunjungan ke wilayah kerja Puskesmas Tamalanrea Makassar dan menyampaikan rencana kegiatan yang akan dilakukan, setelah mendapat persetujuan dari pihak puskemas Tamalanrea Jaya dengan menentukan lokasi dengan melibatkan kader posyandu yang selanjutnya menyepakati jadwal dan waktu pelaksanaan penyuluhan dan pelatihan tentang Tuberculosis.

b. Mekanisme Pelaksanaan Kegiatan

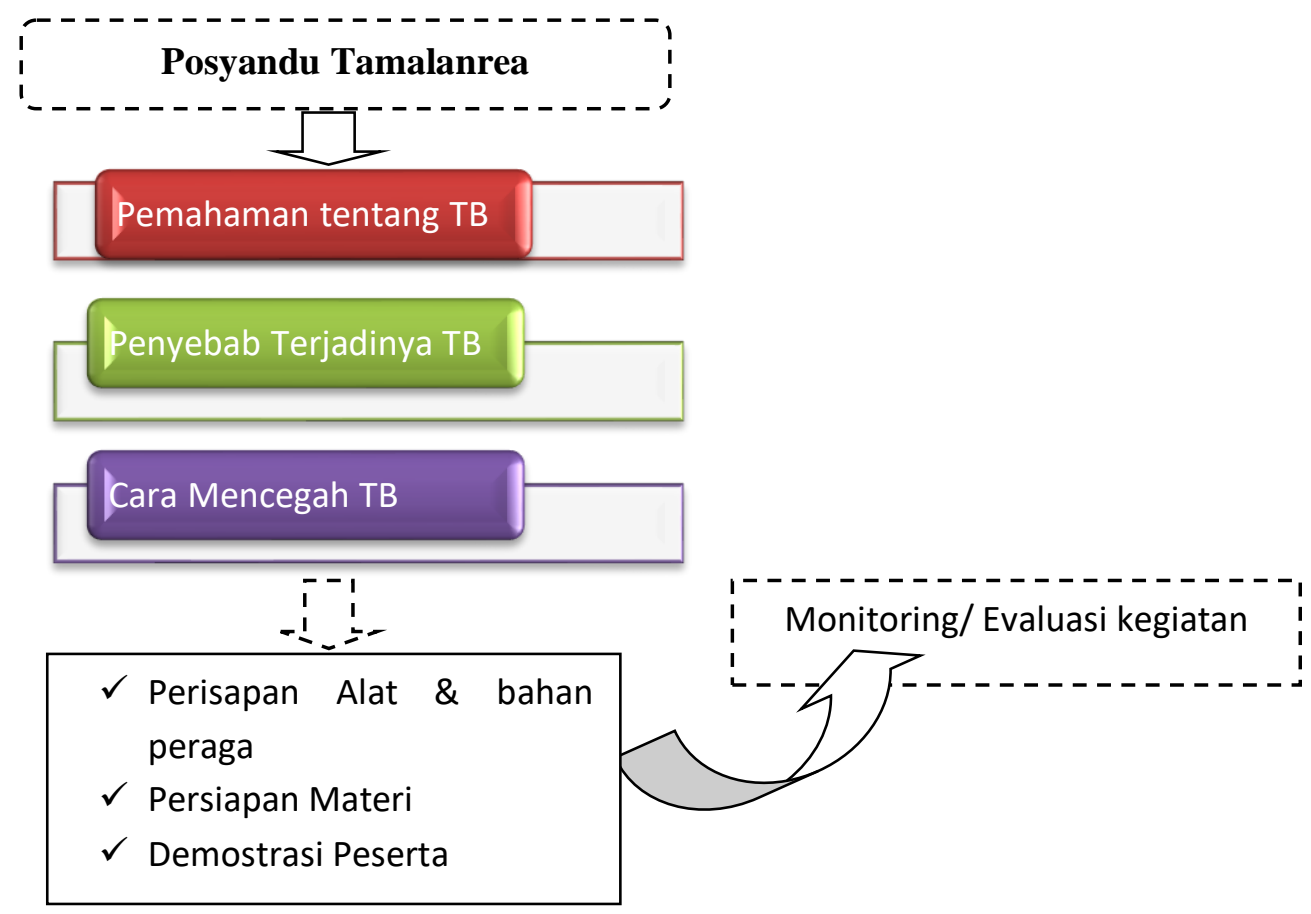

c. Metode dan pelaksanaan

Gambar 1. Mekanisme Pelaksanaan Kegiatan

Kegiatan ini akan dilaksanakan dengan metode ceramah, tanya jawab dan simulasi Pelatihan Tentang Perawatan dan Upaya Pencegahan Tuberkulosis dengan memberikan penyuluhan terlebih dahulu kepada masyarakat terutama keluarga penderita Tuberkulosis. Saat pelaksanaan, Tim akan melakukan evaluasi mengenai pengetahuan dan keterampilan keluarga pasien bagaimana perawatan dan upaya dalam mencegah Tuberkulosis kemudian memberikan materi penyuluhan meliputi pengenalan, pengertian, penyebab, tanda dan gejala, Tuberkulosis pencegahan serta cara atau teknik melakukan agar tidak tertular kepada orang lain. 
Tabel 1. Metode dan Pelaksanaan

\begin{tabular}{|c|c|c|}
\hline No & Materi & Metode \\
\hline 1 & Pengertian Tuberkulosis & Ceramah, Tanya Jawab,Diskusi \\
\hline 2 & Penyebab Tuberkulosis & Ceramah,Tanya Jawab,Diskusi \\
\hline 3 & Manisfestasi Klinik & Ceramah,Tanya Jawab,Diskusi \\
\hline 4 & Komplikasi Tuberkulosis & Ceramah,Tanya Jawab,Diskusi \\
\hline 5 & Penatalaksanaan Tuberkulosis & Ceramah, Tanya Jawab,Diskusi \\
\hline 6 & SOP/ Teknik melakukan pencegahan Tuberculosis & Pelatihan \\
\hline 7 & Evaluasi & Quis \\
\hline
\end{tabular}

\section{Hasil}

a. Karakteristik Peserta

Tabel 2. Karakterisitik Peserta

\begin{tabular}{|l|c|c|}
\hline \multicolumn{1}{|c|}{ Karakteristik } & $\mathrm{n}$ & $\%$ \\
\hline Umur & & \\
$\quad>40$ Tahun & 18 & 56.2 \\
$\quad$ <40 Tahun & 14 & 43.8 \\
\hline Jenis Kelamin & & \\
$\quad$ Laki-laki & 20 & 62.5 \\
Perempuan & 12 & 37.5 \\
\hline Pekerjaan & & \\
PNS & 6 & 18.8 \\
Wiraswasta & 8 & 25.0 \\
Lainnya & 18 & 56.2 \\
\hline
\end{tabular}

b. Respon Peserta

Peserta sangat antusias ini dibuktikan dengan jumlah peserta yang mencapai 40 orang yang mengikuti kegiatan penyuluhan dan pelatihan yang diberikan, dan berharap kegiatan ini terus berlanjut

c. Dampak

Adapun beberapa dampak yang ditimbulkan pada kegiatan ini adalah :

a. Peserta yang mengikuti kegiatan ini mampu memahami apa yang dimaksud tentang Tuberculosis paru, apa penyebabnya dan bagaimana cara mencegahnya

b. Dapat menghindari resiko terjadinya penularan Tuberculosis sesuai dengan apa yang diperoleh pada saat melakukan simulasi dipelatihan yang diikuti

c. Mampu menyiapkan alat dan bahan sederhana pada pasien Tuberculosis pada saat dilakukan perawatan.

\section{Kesimpulan}

Dengan adanya kegiatan ini dapat warga masyarakat yang mempunyai anggota keliarga yang terdiagnosa Tuberculosis sudah dapat melakukan upaya perawatan dan pencegahan penyakit Tuberculosis dengan cara menerpakan pelaithan yang telah diberikan.

\section{Saran}

Diharapkan pihak yang terkait diposyandu lebih aktif dalam penerapan kegiatan yang telah dilaksanakan untuk lebih meningkatkan taraf kesehatan masyarakat dan menurunkan terjadinya penyakit infeksi seperti Tuberculosis.

\section{Daftar Pustaka}

Amalaguswan, Junaid and Fachlevy, A. F. (2017) 'Analisis faktor risiko kejadian penyakit paru obtruktif kronik (ppok) di wilayah kerja puskesmas lepo- lepo kota Kendari tahun 2017’, Jurnal Ilmiah Mahasiswa Kesehatan Masyarakat, 2(6), p. 1.

Iwata, Y. and Uchida, K. (1991) 'Relay Control for a Vibration Isolator Using the Theory of Variable Structure Systems', Transactions of the Japan Society of Mechanical Engineers Series C, 57(534), pp. 382-386. doi: 10.1299/kikaic.57.382.

Kementerian Kesehatan Republik Indonesia (2017) Health Profile of Indonesia 2016, Profil Kesehatan Provinsi Bali. Available at: http://www.depkes.go.id/resources/download/pusdatin/profil-kesehatan-indonesia/Profil-Kesehatan-Indonesia2016.pdf. 
Mulyadi, M. (2011) 'Hubungan Tingkat Kepositivan Pemeriksaan Basil Tahan Asam ( BTA ) dengan Gambaran Luas Lesi Radiologi Toraks pada Penderita Tuberkulosis Paru yang Dirawat Di SMF Pulmonologi RSUDZA Banda Aceh', 31(3), pp. 133137.

Mustikawati, D. E. (2011) 'Pedoman nasional pengendalian tuberkulosis'.

Rahmayuli, P. et al. (2018) 'Hubungan Merokok dengan Hasil Pemeriksaan Bakteriologis Sputum pada', Buletin Farmaterra, 3(2), pp. 88-96. doi: E.ISSN: 2528-410X.

Studi, P. et al. (2018) 'Kata kunci : Tuberkulosis (TB), Promosi Kesehatan, Perawat.', 1(1). 